John Carroll University

Carroll Collected

2018

\title{
Sequestered Alkaloid Defenses in the Dendrobatid Poison Frog Oophaga pumilio Provide Variable Protection from Microbial Pathogens
}

\author{
K.J. Hovey \\ E. M. Seiter \\ Erin E. Johnson \\ John Carroll University, exjohnson@jcu.edu \\ Ralph Saporito \\ John Carroll University, rsaporito@jcu.edu
}

Follow this and additional works at: https://collected.jcu.edu/fac_bib_2018

Part of the Biology Commons, Chemistry Commons, and the Ecology and Evolutionary Biology Commons

\section{Recommended Citation}

Hovey, K. J.; Seiter, E. M.; Johnson, Erin E.; and Saporito, Ralph, "Sequestered Alkaloid Defenses in the Dendrobatid Poison Frog Oophaga pumilio Provide Variable Protection from Microbial Pathogens" (2018). 2018 Faculty Bibliography. 19.

https://collected.jcu.edu/fac_bib_2018/19 


\title{
Sequestered Alkaloid Defenses in the Dendrobatid Poison Frog Oophaga pumilio Provide Variable Protection from Microbial Pathogens
}

\author{
Kyle J. Hovey ${ }^{1} \cdot$ Emily M. Seiter $^{1} \cdot$ Erin E. Johnson ${ }^{1} \cdot$ Ralph A. Saporito ${ }^{1}$
}

\begin{abstract}
Most amphibians produce their own defensive chemicals; however, poison frogs sequester their alkaloid-based defenses from dietary arthropods. Alkaloids function as a defense against predators, and certain types appear to inhibit microbial growth. Alkaloid defenses vary considerably among populations of poison frogs, reflecting geographic differences in availability of dietary arthropods. Consequently, environmentally driven differences in frog defenses may have significant implications regard-ing their protection against pathogens. While natural alkaloid mixtures in dendrobatid poison frogs have recently been shown to inhibit growth of non-pathogenic microbes, no studies have examined the effectiveness of alkaloids against microbes that infect these frogs. Herein, we examined how alkaloid defenses in the dendrobatid poison frog, Oophaga pumilio, affect growth of the known anuran pathogens Aeromonas hydrophila and Klebsiella pneumoniae. Frogs were collected from five locations through-out Costa Rica that are known to vary in their alkaloid profiles. Alkaloids were isolated from individual skins, and extracts were assayed against both pathogens. Microbe subcultures were inoculated with extracted alkaloids to create dose-response curves. Subsequent spectrophotometry and cell counting assays were used to assess growth inhibition. GC-MS was used to characterize and quantify alkaloids in frog extracts, and our results suggest that variation in alkaloid defenses lead to differences in inhibition of these pathogens. The present study provides the first evidence that alkaloid variation in a dendrobatid poison frog is associated with differences in inhibition of anuran pathogens, and offers further support that alkaloid defenses in poison frogs confer protection against both pathogens and predators.
\end{abstract}

Keywords Aeromonas $\cdot$ Chemical defense $\cdot$ Colony-forming unit $\cdot$ Klebsiella $\cdot$ Optical density

\section{Introduction}

Predation and disease are important selective pressures that affect individuals, populations, and communities, thereby driving the evolution of highly diverse defensive strategies (Edmunds 1974). The use of unpalatable or toxic compounds as a defense mechanism is a common adaptation present in a variety of microorganisms, plants, invertebrates, and vertebrates (reviewed in Mebs 2001). Among

Electronic supplementary material The online version of this article (https://doi.org/10.1007/s10886-018-0930-8) contains supplementary material, which is available to authorized users. vertebrates, chemical defenses are widely known for protecting against predators, but they also play a critical role in defending against pathogenic microorganisms (Nicolas and Mor 1995). Amphibians secrete a variety of chemicals from dermal granular glands, including biogenic amines (Daly et al. 1987; Erspamer 1994; McClean et al. 2002), peptides and proteins (Rollins-Smith 2005; Conlon 2011a, b), steroidal bufadienolides (Daly 2004; Erspamer 1994), tetrodotoxin and related analogs (Yotsu-Yamashita et al. 2004; Cardall et al. 2004), indolic alkaloids (Daly and Garraffo 1990; Jeckel et al. 2015a), and an array of lipophilic alkaloids (Daly et al. 2005; Saporito et al. 2012). Amphibians synthesize the majority of these chemical defenses (Toledo and Jared 1995; Daly 1995), but some antimicrobial peptides and metabolites are provided by microbial symbionts (Brucker et al. 2008; Harris et al. 2009; Becker and Harris 2010; Loudon et al. 2014), and lipophilic alkaloids are acquired through diet (Saporito et al. 2009). 
Poison frogs are a polyphyletic group of anurans that have evolved to accumulate and secrete lipophilic alkaloids sequestered from dietary arthropods as a defense. This globallydistributed assemblage is represented by more than 150 species from seven lineages in the families Bufonidae (Melanophryniscus), Dendrobatidae, Eleutherodactylidae (Eleutherodactylus), Mantellidae (Mantella), and Myobatrachidae (Pseudophryne) (reviewed in Saporito et al. 2012). Experimental evidence of alkaloid sequestration in bufonids (Hantak et al. 2013), dendrobatids (Daly et al. 1994), mantellids (Daly et al. 1997), and myobatrachids (Smith et al. 2002) suggests that poison frogs uptake and store an assortment of lipophilic alkaloids (i.e., alkaloid cocktails) obtained from alkaloid-containing ants, mites, beetles, and millipedes (Daly et al. 2002; Saporito et al. 2007a, b, 2009).

Alkaloids in poison frogs are considered an effective defense against predators as a result of their unpalatability and/or toxicity (Hantak et al. 2016; Murray et al. 2016; Bolton et al. 2017), but they may also provide protection from microorganisms including parasites, bacteria, and fungi (Macfoy et al. 2005; Weldon et al. 2006; Grant et al. 2012; Mina et al. 2015). Alkaloids in the bufonid poison frog, Melanophryniscus simplex, occupy muscle and liver tissues, as well as oocytes, in the same relative proportions as the skin, and may deter internal parasites (Grant et al. 2012). Pumiliotoxin 251D, a common alkaloid among dendrobatid poison frogs, appears to be a highly effective deterrent of a tropical mosquito known to parasitize anurans (Weldon et al. 2006). Individual synthetic and natural alkaloids inhibit the growth of the common bacteria Bacillus subtilis (Grampositive) and Escherichia coli (Gram-negative), and the fungus Candida albicans (Macfoy et al. 2005). Most recently, natural alkaloid cocktails isolated from the dendrobatid poison frog, Oophaga pumilio, were found to inhibit growth of those same common microbes to varying degrees (Mina et al. 2015).

Over 1200 unique alkaloids in 28 structural classes have been identified from poison frog skin secretions (Daly et al. 2005; Garraffo et al. 2012; Saporito et al. 2012; Jeckel et al. 2015a; Santos et al. 2016). Poison frogs accumulate between one and 69 of these individual alkaloids in varying quantities (Daly et al. 2005; Saporito et al. 2006, 2007a; Mina et al. 2015). Dendrobatid alkaloid defenses vary considerably in diversity and quantity within and among populations primarily as a result of differences in the local availability of dietary arthropods (Myers and Daly 1976; Daly et al. 1987, 2008a; Saporito et al. 2006, 2007a), although factors such as species, sex, age, and life stage are also important determinants of variation (Saporito et al. 2010a, b, 2012; Stynoski et al. 2014; Jeckel et al. 2015b). Given that antimicrobial activity differs among individual alkaloids (Macfoy et al. 2005) and among natural alkaloid cocktails (Mina et al. 2015), environmentally-driven differences in alkaloid defenses may influence protection against natural pathogens at the population level. Specifically, populations with greater quantities of alkaloids and more diverse alkaloid cocktails likely benefit from enhanced protection from pathogenic microorganisms, although this has not yet been tested.

Numerous pathogenic microorganisms infect amphibians, including opportunistic Gram-negative bacteria, the chytrid fungus Batrachochytrium dendrobatidis $(B d)$, mycobacteria, ranaviruses, water molds, trematodes, and other various parasites (Taylor et al. 2001; Green et al. 2002; Schadich and Cole 2010). Opportunistic Gramnegative bacteria have been frequently implicated in bacterial dermatosepticemia, a fatal systemic infectious disease in frogs that has been linked to population declines and extirpations in the wild (Nyman 1986; Bradford 1991; Sherman and Morton 1993) and mass mortalities in captivity (Green et al. 1999). Although numerous Gram-negative bacilli may cause dermatosepticemia, bacteria such as Aeromonas hydrophila have been most frequently implicated as the etiological agent, and host susceptibility depends on the amphibian species as well as environmental, stress, dietary, health, and immune status factors (Schadich and Cole 2010). For instance, Schadich and Cole (2010) isolated the Gram-negative A. hydrophila, Klebsiella pneumoniae, and Proteus mirabilis from infected brown tree frogs (Litoria ewingii) during a dermatosepticemia epizootic, and determined that $K$. pneumoniae was the most virulent in healthy frogs. Although antimicrobial peptide defenses are thought to have evolved as a secondary, broad-spectrum immune defense (Nicolas and Mor 1995; Roelants et al. 2013) and are effective in that role (Simmaco et al. 1998a, b; Zasloff 2002; Rollins-Smith 2005), there is a fundamental gap in our understanding of the role that sequestered alkaloid defenses serve in defending poison frogs from infection.

Research on the antimicrobial activity of alkaloid defenses in frogs (Macfoy et al. 2005; Mina et al. 2015) has focused on the dendrobatid poison frog, O. pumilio, a terrestrial dendrobatid frog whose alkaloid defenses are relatively wellcharacterized and vary considerably with geographic location at both small and large spatial scales (Saporito et al. 2006, 2007a, 2010a). The substantial variability in O. pumilio alkaloid defenses, in addition to an abundance of previouslyidentified alkaloids, makes $O$. pumilio an ideal study organism in which to examine ecologically relevant antimicrobial activity of sequestered alkaloid defenses. The aim of the present study is to examine the extent to which the variable alkaloid defenses in a dendrobatid poison frog, $O$. pumilio, inhibit the growth of the anuran pathogens $A$. hydrophila and K. pneumoniae. 


\section{Methods and Materials}

Study Sites and Frog Collections A total of 70 adult O. pumilio were collected from five lowland tropical rainforest sites throughout eastern Costa Rica ( $n=14$ per site), which were selected based on known differences in the alkaloid defenses (i.e., number and quantity of unique alkaloids and alkaloid structural classes) of $O$. pumilio from each site (alkaloid data from Saporito et al. 2007a). Frogs were collected from each of the following locations: La Selva Biological Station $\left(10^{\circ} 26^{\prime}\right.$ N, 83 $59^{\prime}$ W; 7 males and 7 females), Finca los Nacientes $\left(10^{\circ} 21^{\prime} 53^{\prime \prime} \mathrm{N}, 84^{\circ} 8^{\prime} 6 " \mathrm{~W} ; 8\right.$ males and 6 females), Tortuguero $\left(10^{\circ} 35^{\prime} 14^{\prime \prime} \mathrm{N}, 83^{\circ} 31^{\prime} 34^{\prime \prime} \mathrm{W} ; 7\right.$ males and 7 females), Río Palmas ( $10^{\circ} 10^{\prime} 16^{\prime \prime} \mathrm{N}, 8^{\circ} 36^{\prime} 26^{\prime \prime} \mathrm{W} ; 8$ males and 6 females), and Gandoca ( $9^{\circ} 35^{\prime} 03^{\prime \prime} \mathrm{N}, 82^{\circ} 37^{\prime} 13^{\prime \prime} \mathrm{W} ; 7$ males and 7 females). Frogs were collected within a single $45 \mathrm{~m} \times 45 \mathrm{~m}$ collection plot at each site, sexed based on gular skin patches (Donnelly 1989), measured for snout-to-vent length (SVL), and euthanized by freezing at $-20{ }^{\circ} \mathrm{C}$. Frog skins were stored individually in $4 \mathrm{~mL}$ of $100 \%$ methanol contained in glass vials sealed with Teflon-lined caps ("methanol extract").

Alkaloid Fractionations Alkaloids were extracted from frog skins using the procedure outlined in Saporito et al. (2010a), which is briefly described here. One $\mathrm{mL}$ of each methanol extract was transferred to a $10 \mathrm{~mL}$ conical vial and acidified with $50 \mu \mathrm{L}$ hydrochloric acid $(1 \mathrm{~N})$. Each sample was then mixed and evaporated to a volume of $100 \mu \mathrm{L}$ using nitrogen gas, followed by dilution with $200 \mu \mathrm{L}$ deionized water. Samples were then extracted with four $300 \mu \mathrm{L}$ portions of hexane. The organic hexane layer was then disposed of, and the remaining aqueous solution was basified with sodium bicarbonate. Once basicity was verified with $\mathrm{pH}$ paper, each sample was extracted with three portions of $300 \mu \mathrm{L}$ ethyl acetate. Anhydrous sodium sulfate was added to remove remaining trace amounts of water. The remaining samples were carefully evaporated to dryness with nitrogen gas. Alkaloid fractions were resuspended in $100 \mu \mathrm{L}$ of methanol and stored at $-20^{\circ} \mathrm{C}$.

Alkaloid Analysis To determine which unique alkaloids were present in extracts, and in what quantities $(\mu \mathrm{g})$, samples of individual frog extracts containing a nicotine standard $(1 \mu \mathrm{g} /$ $10 \mu \mathrm{L} ;(-)$-nicotine $\geq 99 \%$, Sigma-Aldrich) were analyzed using gas chromatography-mass spectrometry (GC-MS). Analyses were performed on a Varian Saturn $2100 \mathrm{~T}$ ion trap MS coupled to a Varian $3900 \mathrm{GC}$ with a $30 \mathrm{~m} \times 0.25 \mathrm{~mm}$ ID Varian FactorFour VF-5 ms fused silica column. The temperature program increased from $100{ }^{\circ} \mathrm{C}$ to $280{ }^{\circ} \mathrm{C}$ at a rate of $10{ }^{\circ} \mathrm{C} / \mathrm{min}$ and helium was the carrier gas (flow rate of $1 \mathrm{~mL} / \mathrm{min}$ ). Samples of alkaloid fractions were analyzed using both electron impact (EI) MS and chemical ionization (CI) MS, with methanol as the CI reagent. EI-MS for alkaloid identification and quantification was conducted in triplicate for each frog and CI-MS for alkaloid identification was performed once. In total, four $1 \mu \mathrm{L}$ samples from each of 70 frogs' alkaloid extract were analyzed $(n=280$ GC-MS runs).

Unique alkaloids were identified by comparing and matching retention times and mass spectral data of individual peaks, largely with data from the alkaloid library presented in Daly et al. 2005 (but also Daly et al. 2007, 2008a, b, 2009; Saporito et al. 2007a; Garraffo et al. 2012; Grant et al. 2012; Fitch et al. 2013; Andriamaharavo et al. 2015), which includes alkaloid assignment data and confirmed/proposed alkaloid structures. Synthetic standards for DHQ 195A, DHQ 211A, and 5,8-I 235B (N. Toyooka, University of Toyama) were used in identification, and to calibrate the retention times for other alkaloids when comparing them to previously identified alkaloids. The quantity of unique alkaloids present in each frog was calculated by comparing each alkaloid's peak to an internal nicotine standard ( $1 \mu \mathrm{g} / 10 \mu \mathrm{L} ;(-)$-nicotine $\geq 99 \%$, Sigma-Aldrich) using Varian MS Workstation v.6.9 SPI; however, it should be noted that this type of quantitation should be considered semi-quantitation, given that ionization likely differs between nicotine and frog alkaloids as well as among different alkaloids (for further discussion, see Andriamaharavo et al. 2015).

Culture and Maintenance of Microbes Liquid cultures of Aeromonas hydrophila (ATCC 35654) and Klebsiella pneumoniae subsp. pneumoniae (ATCC 13883) were incubated in tryptic soy broth (TSB; Remel) for $18 \mathrm{hr}$ at $30{ }^{\circ} \mathrm{C}$ (A. hydrophila) or $37^{\circ} \mathrm{C}$ (K. pneumoniae) with $200 \mathrm{rpm}$ agitation. All cultures were grown to the mid-log phase prior to dilution for the growth inhibition assays.

Microbial Growth Inhibition Assays Optical density (OD) assays were adapted from an assay described by Mina et al. (2015). Based on pilot growth experiments, cultures were diluted with TSB to a ratio of 1:10 (A. hydrophila) or 1:5 (K. pneumoniae) and equal volumes (200 $\mu \mathrm{L}$; "subcultures") were immediately aliquotted into 96-well flat-bottom microplate (Falcon). Aliquots of alkaloids from individual frogs and pure methanol were added in the amount of 2.4 and $4.8 \mu \mathrm{L}$ to four replicate wells (subsamples) each. Methanol alone served as the vehicle control given that alkaloid extracts were dissolved in methanol. Treatment volumes were selected based on pilot experiments which indicated that $9.6 \mu \mathrm{L}$ of methanol in $200 \mu \mathrm{L}$ of A. hydrophila was highly inhibitory and would likely obscure any inhibition due to natural alkaloid extracts; while treatments with $2.4 \mu \mathrm{L}$ and $4.8 \mu \mathrm{L}$ of methanol were 
inhibitory compared to negative controls, differences between methanol and alkaloid treatments were still evident at these volumes. Moreover, the treatment volumes are considered ecologically relevant for what microbes may be exposed to on frog skin, representing $0.6 \%$ and $1.2 \%$, respectively, of the total quantity of alkaloids present in each individual frog skin.

Immediately following inoculation, the microplate was placed in a Fisher Scientific Multiskan FC microplate reader inside an incubator (ThermoForma) at the microbe's corresponding growth temperature. A baseline measurement of each subculture's OD at $620 \mathrm{~nm}\left(\mathrm{OD}_{620}\right)$ was recorded prior to incubation to verify that all subcultures began at an OD similar to those in pilot experiments $\left( \pm 0.02 \mathrm{OD}_{620}\right)$ to account for random variation. A 24-hr program that recorded $\mathrm{OD}_{620}$ at 15-min intervals after shaking the plate at medium speed for five seconds was used to create 24-hr growth curves for each treatment. The final $\mathrm{OD}_{620}$ readings of subsamples per treatment were averaged for use in statistical analyses of OD assays.

Colony-forming unit (CFU) assays were used to assess the viability of the aforementioned subcultures after a 24-hr incubation period with natural alkaloid extracts and methanol treatments. Immediately following the final measurement of OD assays, three randomly-selected subsamples from each treatment were serially-diluted in tenfold increments up to $10^{-7}$ using microplates. Ten microliters of each serial dilution were then plated on TSA in square $6 \times 6$ gridded petri dishes (Fisherbrand) and incubated until single colonies (i.e., colonyforming units) formed. Once CFUs were visible, the number of CFUs at each dilution $\left(10^{-1}-10^{-7}\right)$ for each subsample was recorded. When CFU counts exceeded 30 , colonies tended to grow into one another and it became difficult to accurately quantify CFUs. Therefore, the serial dilution that grew CFUs nearest to 30 in number, while still being equal to or below 30, was used to calculate the original cell density (OCD; CFU/mL; equation below) of each subsample. The average of each treatment's three subsample OCD values was used in statistical analyses.

Original cell density $(\mathrm{CFU} / \mathrm{mL})$

$$
=\frac{(\text { Colony }- \text { forming units })}{(\text { Dilution factor }) \times(\text { Volume of aliquot in } \mathrm{mL})}
$$

In the OCD equation, dilution factor refers to the magnitude of dilution of the quantified aliquot (e.g., $10^{-7}$ ), and volume of aliquot in $\mathrm{mL}$ refers to the volume of each subsample's dilutions that were plated $(10 \mu \mathrm{L}$ in this case, or $0.01 \mathrm{~mL})$.

Statistical Analyses Since alkaloid composition is a collective measure of the number, type, and quantity of alkaloids within individual frog skins, nonmetric multidimensional scaling (NMDS) was used to visualize differences in alkaloid composition among populations. Analysis of similarity (ANOSIM) was used to detect statistical differences in alkaloid composition among these populations. Multivariate analyses were based on Bray-Curtis similarity matrices and performed using PRIMER-E version 5.

A nested one-way analysis of variance (ANOVA) was used to examine variation of growth inhibition within individual frog alkaloid treatments in both OD and CFU assays for each microbe. A two-tailed, unpaired, independent samples $t$-test was used to determine the presence of a dose-response relationship between 2.4 and $4.8 \mu \mathrm{L}$ doses in both OD and CFU assays for each microbe. The effects of alkaloids on microbial growth were assessed using one-way ANOVA; final optical densities (growth inhibition) and CFU/mL after treatment (remaining viable cells) of frog alkaloid and methanol treatments in the $4.8 \mu \mathrm{L}$ treatment were compared among populations and for each pathogen. Multiple comparisons (Tukey's HSD) were used to identify differences in microbial growth inhibition of frog alkaloids from each population compared to methanol treatments. To determine the effects of frog population and sex on growth inhibition, two-way ANOVA was conducted for each assay with each microbe. Linear regression analyses were performed to assess relationships between alkaloid composition (diversity and quantity) and growth inhibition (OD and CFU assays) for each microbe, and to test the relationship between OD and CFU assays for each microbe. All parametric statistical analyses were performed using SPSS version 14.0 and GraphPad Prism version 6.05.

\section{Results}

Alkaloid Analysis GC-MS analysis of 70 Oophaga pumilio from five Costa Rican populations resulted in the identification of 353 unique alkaloids (including isomers) represented by 19 different structural classes (see Online Resource Table 1 for the most common alkaloids identified in each population and Online Resource Table 2 for all identified alkaloids). The majority of these alkaloids are derived from mites and ants. Alkaloid composition of $O$. pumilio differed significantly among the five populations (Global $R=0.91$; $P=0.001$; Online Resource Fig. 1a), but not between sexes (Global $R=0.03 ; P=0.966$ ). Frogs from Finca los Nacientes contained the largest number and greatest quantity of alkaloids, while frogs from Gandoca contained the lowest number of alkaloids and contained similarly low quantities of alkaloids as frogs from La Selva (see Table 1 for details on alkaloid composition by population and sex). In general, frogs from Tortuguero and Finca los Nacientes contained about three times as much alkaloid (in terms of quantity, $\mu \mathrm{g}$ per frog skin) as frogs from La Selva, Río Palmas, and Gandoca (Online Resource Fig. 1b). 
Table 1 Diversity (alkaloids per frog skin) and quantity ( $\mu \mathrm{g}$ per frog skin) of alkaloid defenses from each population of Oophaga pumilio

\begin{tabular}{|c|c|c|c|c|c|c|c|c|c|c|c|c|}
\hline & $\begin{array}{l}\text { Average } \\
\text { diversity }\end{array}$ & $\begin{array}{l}\text { Average } \\
\text { + } \\
\text { diversity }\end{array}$ & $\begin{array}{l}\text { Average } \\
\widehat{\delta} \\
\text { diversity }\end{array}$ & $\begin{array}{l}\text { Total } \\
\text { diversity }\end{array}$ & $\begin{array}{l}\text { Total }+ \\
\text { diversity }\end{array}$ & $\begin{array}{l}\text { Total } \widehat{\jmath} \\
\text { diversity }\end{array}$ & $\begin{array}{l}\text { Average } \\
\text { quantity }\end{array}$ & $\begin{array}{l}\text { Average } \\
q \\
\text { quantity }\end{array}$ & $\begin{array}{l}\text { Average } \\
\delta \\
\text { quantity }\end{array}$ & $\begin{array}{l}\text { Total } \\
\text { quantity }\end{array}$ & $\begin{array}{l}\text { Total } q \\
\text { quantity }\end{array}$ & $\begin{array}{l}\text { Total } \widehat{0} \\
\text { quantity }\end{array}$ \\
\hline Tortuguero & 37 & 39 & 36 & 521 & 272 & 249 & 986 & 1224 & 748 & 13,807 & 8567 & 5239 \\
\hline La Selva & 33 & 36 & 30 & 458 & 250 & 208 & 344 & 462 & 225 & 4811 & 3233 & 1578 \\
\hline Finca los Nacientes & 54 & 55 & 53 & 758 & 441 & 317 & 1181 & 1219 & 1130 & 16,528 & 9750 & 6778 \\
\hline Río Palmas & 39 & 42 & 36 & 548 & 334 & 214 & 264 & 295 & 223 & 3697 & 2357 & 1340 \\
\hline Gandoca & 26 & 21 & 31 & 364 & 147 & 217 & 344 & 280 & 524 & 4812 & 1148 & 3665 \\
\hline All populations & 38 & 39 & 37 & 2649 & 1444 & 1205 & 624 & 677 & 564 & 43,656 & 25,056 & 18,600 \\
\hline
\end{tabular}

Total diversity represents the sum number of alkaloids identified in all 14 frogs from each location. Total quantity represents the sum quantity of alkaloid present in all 14 frogs from each location

Alkaloid quantity and diversity are also strongly correlated $\left(F_{1,68}=49.47, P<0.001 ; R^{2}=0.421\right.$; Online Resource Fig. 2), although the relationship appears to be exponential rather than linear. In general, frogs containing higher quantities of alkaloids also possessed more diverse alkaloid cocktails, but fewer new types of alkaloids were represented with increasing alkaloid quantities.

Dose-Response Relationship between $2.4 \mu \mathrm{L}$ and $4.8 \mu \mathrm{L}$ Treatments Exposure of both A. hydrophila and $K$. pneumoniae to increased doses of alkaloid treatments indicates that there is a clear dose-response relationship between treatments and microbial growth inhibition. With both A. hydrophila and $K$. pneumoniae, $4.8 \mu \mathrm{L}$ treatments resulted in consistently lower final optical density readings $\left(t_{138}=\right.$ $\left.13.19, P<0.001 ; t_{138}=10.15, P<0.001\right)$ and reduced viable cell counts $\left(t_{138}=8.47, P<0.001 ; t_{138}=6.65, P<0.001\right)$, respectively, in comparison to $2.4 \mu \mathrm{L}$ treatments. In accordance with the dose-response relationship, differences in microbial growth inhibition between control and alkaloid treatments were more evident in $4.8 \mu \mathrm{L}$ treatments; therefore, the results for all following assays and comparisons are reported for $4.8 \mu \mathrm{L}$ treatments only (Figs. 1, 2, 3, 4 and 5).

Aeromonas hydrophila Optical Density Assays Mean optical density of $A$. hydrophila treated with alkaloid cocktails from the five locations of $O$. pumilio differed significantly among the five populations of $O$. pumilio and methanol controls $\left(F_{5,78}=13.04 ; P<0.001 ;\right.$ Fig. $\left.1 \mathrm{a}\right)$; however, mean optical density of $A$. hydrophila treated with alkaloids from individual frogs did not differ within samples $\left(F_{18,312}=1.09 ; P=0.360\right)$. The mean optical density of $A$. hydrophila treated with alkaloids from Tortuguero, La Selva, and Finca los Nacientes frogs was significantly less than the methanol control, while the mean optical density of $A$. hydrophila treated with alkaloids from Río Palmas and Gandoca frogs showed no change.
Fig. 1 Mean final optical densities $\left(\mathrm{OD}_{620}\right)(\mathbf{a})$ and viable cell counts $(\mathrm{CFU} / \mathrm{mL})(\mathbf{b})$ of Aeromonas hydrophila after treatment with alkaloid cocktails extracted from Oophaga pumilio. The dotted line represents the mean $\mathrm{OD}_{620}$ and $\mathrm{CFU} / \mathrm{mL}$ for the methanol control, error bars represent \pm 1 SEM, and treatment means that are significantly different from each other are indicated by different letters (Tukey's HSD, $P<0.05$ )
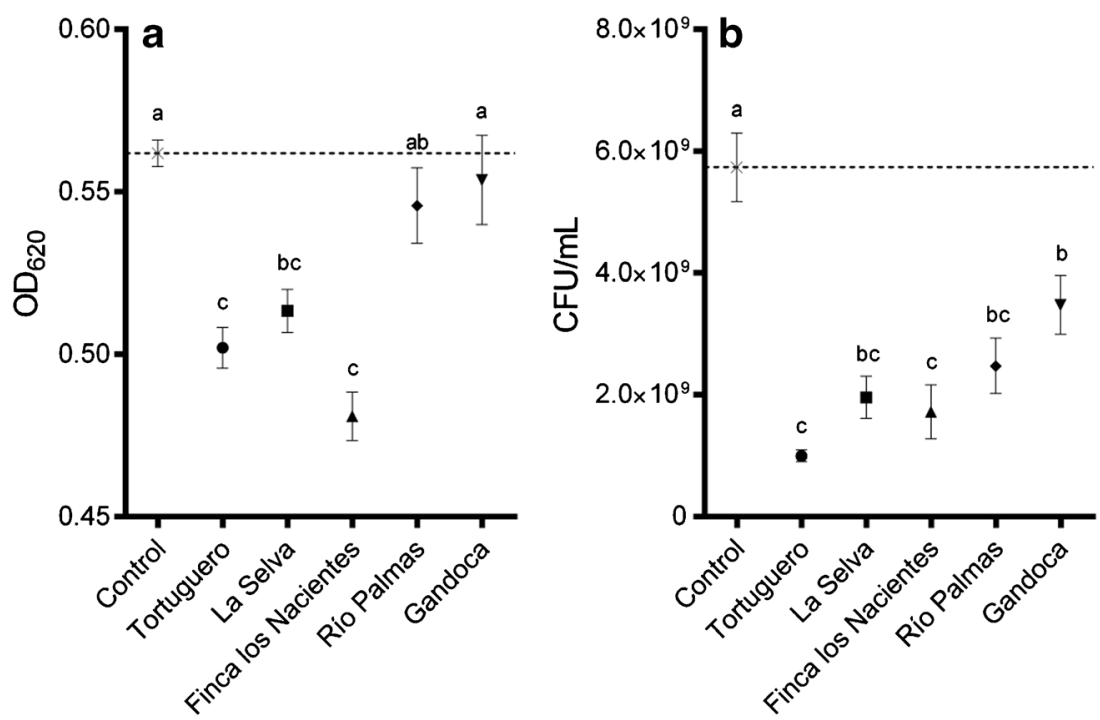
Fig. 2 Mean final optical densities $\left(\mathrm{OD}_{620}\right)(\mathbf{a})$ and viable cell counts $(\mathrm{CFU} / \mathrm{mL})(\mathbf{b})$ of Klebsiella pneumoniae after treatment with alkaloid cocktails extracted from Oophaga pumilio. The dotted line represents the mean $\mathrm{OD}_{620}$ and $\mathrm{CFU} / \mathrm{mL}$ for the methanol control, error bars represent \pm 1 SEM, and treatment means that are significantly different from each other are indicated by different letters (Tukey's HSD, $P<0.05$ )
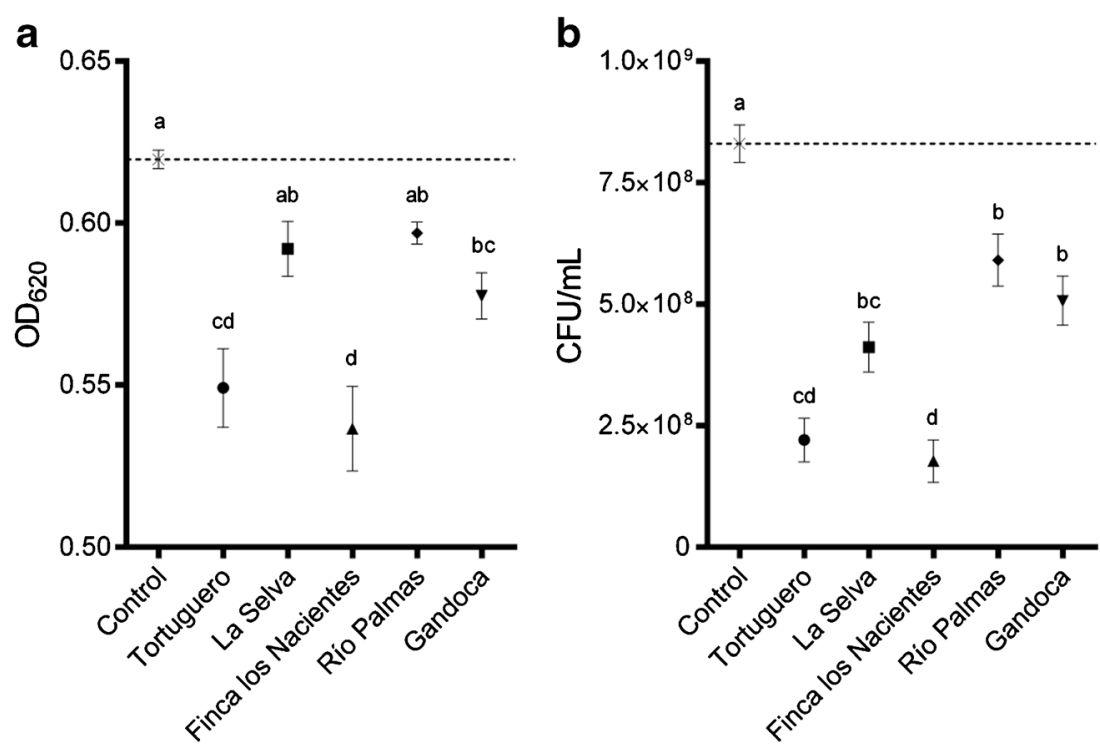

There was no interaction between the effects of frog population and sex for optical density assays with $A$. hydrophila $\left(F_{4,60}=0.92, P=0.459\right)$.

Aeromonas hydrophila Colony-Forming Unit Assays The number of viable cells of $A$. hydrophila treated with alkaloid cocktails differed significantly among the five populations of $O$. pumilio and methanol controls $\left(F_{5,78}=15.89 ; P<0.001\right.$; Fig. 1b); however, mean viable cell counts of $A$. hydrophila treated with alkaloids from individual frogs did not differ within samples $\left(F_{12,234}=0.90 ; P=0.545\right)$. The CFU's recovered from A. hydrophila treated with alkaloids from all populations were significantly less than the methanol control. There was a statistically significant interaction between frog population and sex in CFU assays with $A$. hydrophila $\left(F_{4,60}=\right.$ $3.79, P=0.008)$, although there was no difference in original cell density between sexes after treatment with alkaloid cocktails from frogs $\left(F_{1,60}=0.99, P=0.324\right)$; in other words, the more inhibitory sex varied among populations.
Klebsiella pneumoniae Optical Density Assays Mean optical density of $K$. pneumoniae treated with alkaloid cocktails from the five locations of $O$. pumilio differed significantly among the five populations of $O$. pumilio and methanol controls $\left(F_{5,78}=12.67 ; P<0.001 ;\right.$ Fig. $\left.2 \mathrm{a}\right)$; however, mean optical density of $K$. pneumoniae treated with alkaloids from individual frogs differed within samples $\left(F_{18,312}=2.93 ; P<0.001\right)$. The mean optical density of $K$. pneumoniae treated with alkaloids from Tortuguero, Finca los Nacientes, and Gandoca frogs was significantly less than the methanol control, while the mean optical density of $K$. pneumoniae treated with alkaloids from La Selva and Río Palmas frogs showed no change. There was no interaction between the effects of frog population and sex for optical density assays with $K$. pneumoniae $\left(F_{4,60}=1.99, P=0.107\right)$.

Klebsiella pneumoniae Colony-Forming Unit Assays The number of viable cells of $K$. pneumoniae treated with alkaloid cocktails differed significantly among the five populations of
Fig. 3 Relationship between optical density and colonyforming unit assays for (a) Aeromonas hydrophila and (b) Klebsiella pneumoniae treated with alkaloids extracted from Oophaga pumilio a

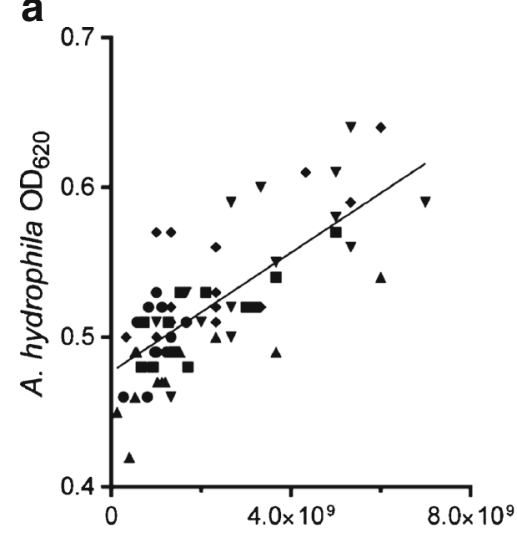

A. hydrophila CFU/mL b

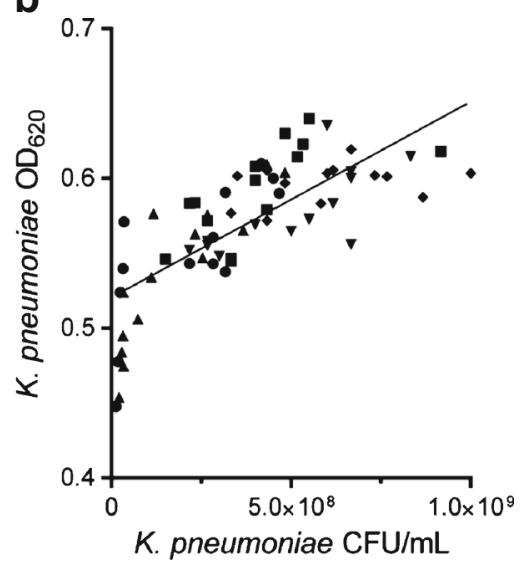

- Tortuguero - La Selva $\Delta$ Finca los Nacientes $\bullet$ Río Palmas $\boldsymbol{\nabla}$ Gandoca 
Fig. 4 Relationship between alkaloid profiles of individual Oophaga pumilio and corresponding growth inhibition of Aeromonas hydrophila [(a) alkaloid diversity (alkaloids per frog skin) and optical density assay; (b) alkaloid diversity (alkaloids per frog skin) and colony-forming unit assay; (c) alkaloid quantity ( $\mu \mathrm{g}$ per frog skin) and optical density assay; (d) alkaloid quantity ( $\mu \mathrm{g}$ per frog skin) and colony-forming unit assay]
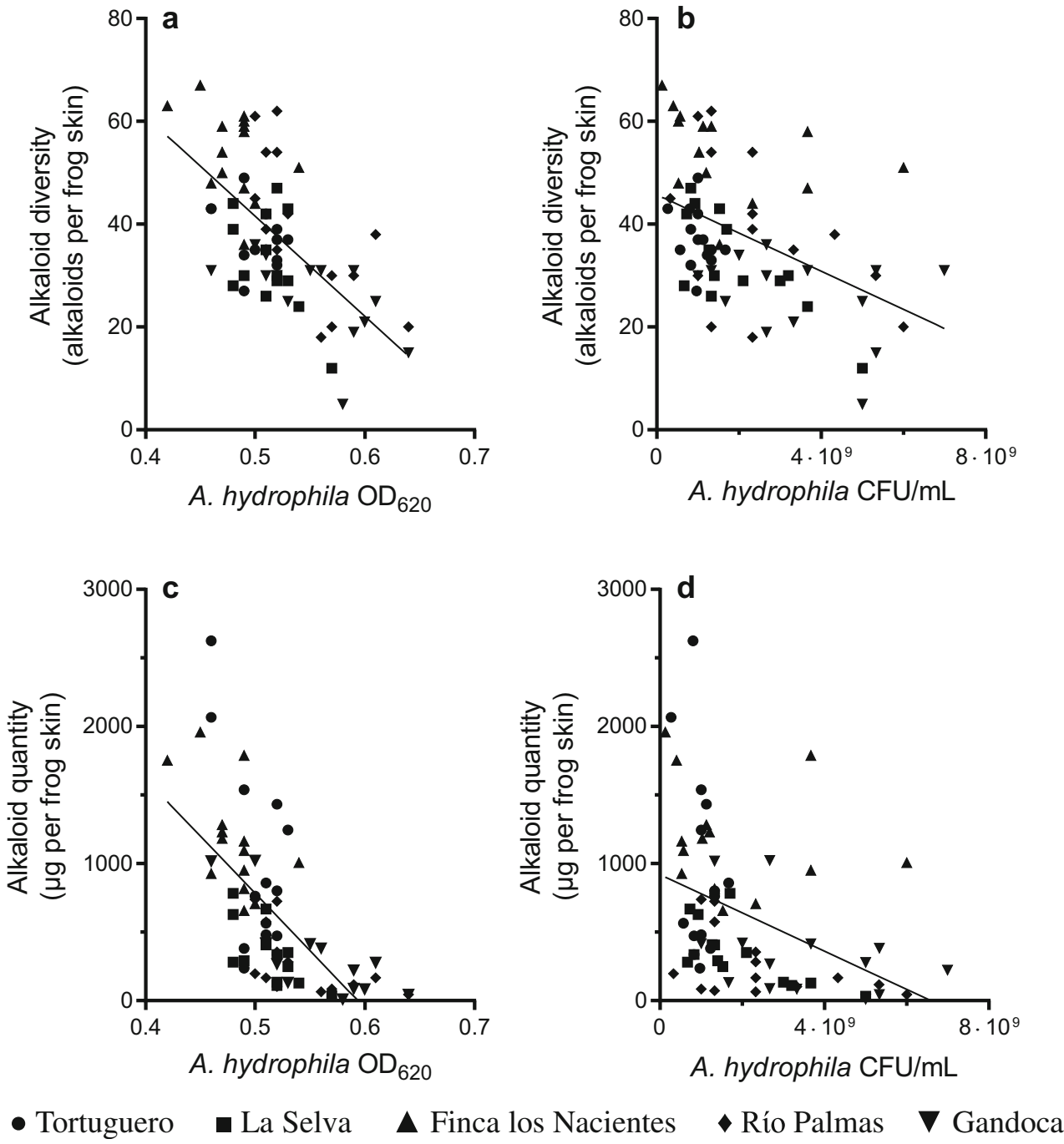

O. pumilio and methanol controls $\left(F_{5,78}=26.41 ; P<0.001\right.$; Fig. 2b); however, mean viable cell counts of $K$. pneumoniae treated with alkaloids from individual frogs did not differ within samples $\left(F_{12,234}=0.52 ; P=0.899\right)$. The CFU's recovered from $K$. pneumoniae treated with alkaloids from all populations was significantly less than the methanol control. There was a statistically significant interaction between frog population and sex in colony-forming unit assays with $K$. pneumoniae $\left(F_{4,60}=2.81, P=0.033\right)$, although there was no difference in original cell density between sexes after treatment with alkaloid cocktails from frogs $\left(F_{1,60}=0.14, P=\right.$ $0.706)$; similarly to colony-forming unit assays with A. hydrophila, the more inhibitory sex varied among populations.

Relationship between Optical Density and Colony-Forming Unit Assays Optical density assays and colony-forming unit assays were strongly correlated for both A. hydrophila $\left(F_{1,68}=80.88, P<0.001, R^{2}=0.543\right.$; Fig. $\left.3 \mathrm{a}\right)$ and $K$. pneumoniae $\left(F_{1,68}=85.52, P<0.001, R^{2}=0.557\right.$; Fig. 3b). The patterns in growth inhibition among $O$. pumilio populations were identical between the two assays for both microbes (Figs. 1 and 2).

Relationships between Alkaloid Composition and Growth Inhibition Alkaloid-based growth inhibition of A. hydrophila was correlated with both alkaloid diversity and composition of O. pumilio (Fig. 4). Alkaloid diversity was a moderate predictor of growth inhibition by proxy of both OD $\left(F_{1,68}=48.60\right.$, $P<0.001, \mathrm{R}^{2}=0.417$; Fig. $\left.4 \mathrm{a}\right)$ and CFU assays $\left(F_{1,68}=\right.$ 17.92, $P<0.001, R^{2}=0.209$; Fig. $4 b$ ). Alkaloid quantity was also a moderate predictor of growth inhibition by proxy of both OD $\left(F_{1,68}=53.46, P<0.001, R^{2}=0.440\right.$; Fig. $\left.4 \mathrm{c}\right)$ and CFU assays $\left(F_{1,68}=13.79, P<0.001, R^{2}=0.169\right.$; Fig. $\left.4 \mathrm{~d}\right)$.

Alkaloid quantity, but not diversity, was a better predictor of growth inhibition of $K$. pneumoniae compared to A. hydrophila (Figs. 4 and 5). Alkaloid diversity was a moderately weak predictor of both OD $\left(F_{1,68}=19.05, P<0.001\right.$, $R^{2}=0.219$; Fig. 5a) and CFU assays $\left(F_{1,68}=34.22, P<0.001\right.$, $R^{2}=0.335$; Fig. 5b). However, alkaloid quantity was a 
Fig. 5 Relationship between alkaloid profiles of individual Oophaga pumilio and corresponding growth inhibition of Klebsiella pneumoniae [(a) alkaloid diversity (alkaloids per frog skin) and optical density assay; (b) alkaloid diversity (alkaloids per frog skin) and colony-forming unit assay; (c) alkaloid quantity ( $\mu \mathrm{g}$ per frog skin) and optical density assay; (d) alkaloid quantity ( $\mu \mathrm{g}$ per frog skin) and colony-forming unit assay]
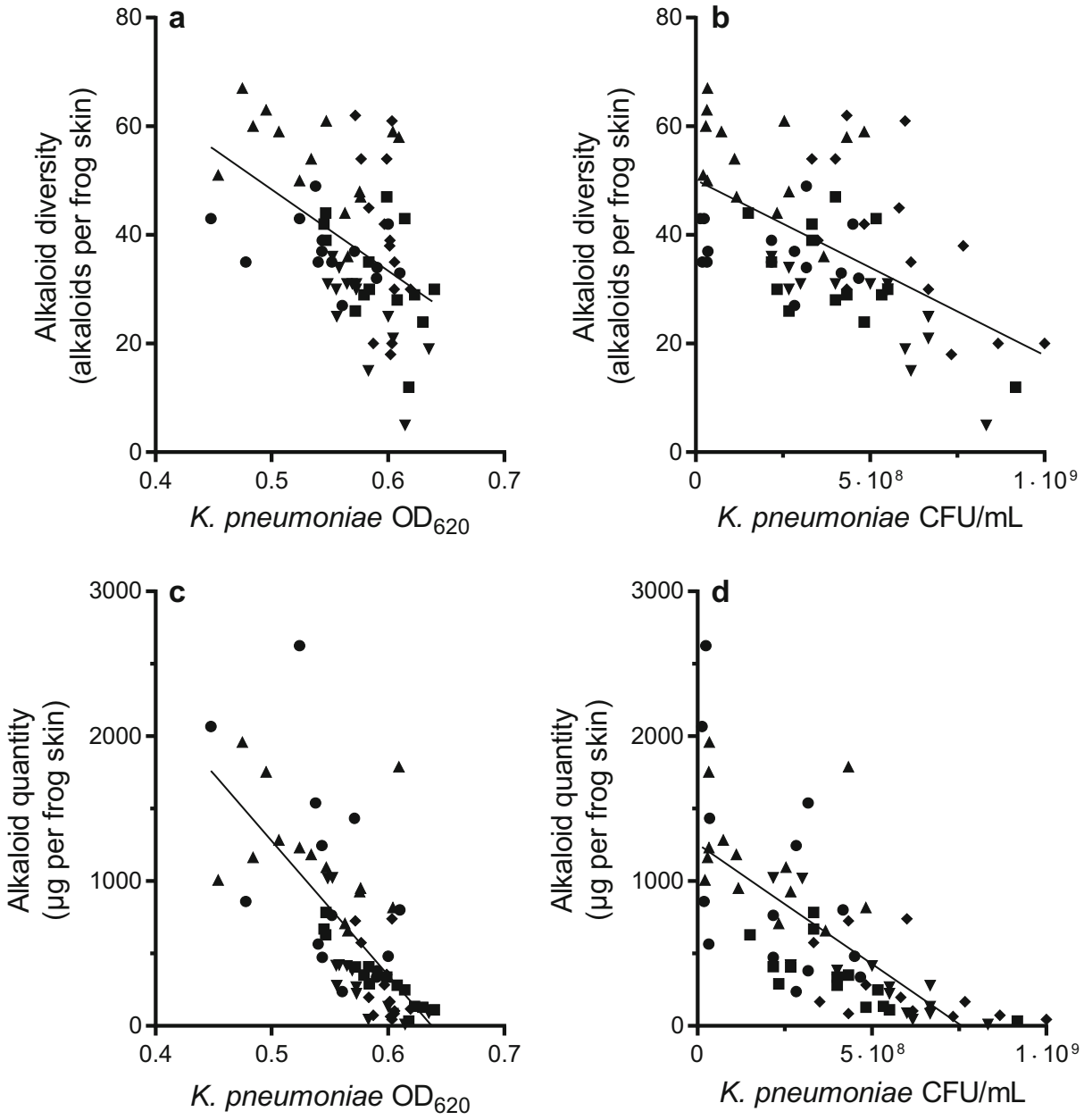

- Tortuguero

- La Selva

$\Delta$ Finca los Nacientes

- Río Palmas

$\boldsymbol{\nabla}$ Gandoca

comparatively stronger predictor of both OD $\left(F_{1,68}=63.35\right.$, $P<0.001, R^{2}=0.482$; Fig. $\left.5 \mathrm{c}\right)$ and CFU assays $\left(F_{1,68}=68.73\right.$, $P<0.001, R^{2}=0.503$; Fig. 5d) for $K$. pneumoniae.

\section{Discussion}

Alkaloid-based chemical defenses in poison frogs are unpalatable and/or toxic to a variety of invertebrates and vertebrates, and function accordingly as a defense against predators (Brodie and Tumbarello 1978; Fritz et al. 1981; Szelistowski 1985; Weldon et al. 2013; Stynoski et al. 2014; Hantak et al. 2016; Hovey et al. 2016; Murray et al. 2016). Individual alkaloids and natural alkaloid cocktails from the dendrobatid poison frog $O$. pumilio have also recently been shown to inhibit the growth of select microbes (Macfoy et al. 2005; Mina et al. 2015), suggesting that alkaloids may provide a dual defense against both predators and infection. The present study supports this hypothesis and demonstrates that sequestered alkaloid defenses from various populations of $O$. pumilio inhibit the growth of microbes that infect anurans and contribute to substantial mortality in captivity and in the wild (i.e., pathogenic microbes); however, populations of O. pumilio also appear to vary in their ability to inhibit these pathogens.

Poison frogs accumulate unique suites of alkaloids gradually over the course of their lifetime as they consume alkaloidcontaining arthropods (Saporito et al. 2009). In the present study, the composition of alkaloid defenses (i.e., quantity and diversity) differed significantly among populations, reflecting disparities in the type and availability of dietary arthropods at each location (Saporito et al. 2007a, 2009, 2012). Similarly, the extent of growth inhibition of both A. hydrophila and K. pneumoniae differed significantly among populations, most likely as a direct result of each population's distinct alkaloid composition.

Alkaloid quantity and alkaloid diversity are strongly correlated in the studied populations of $O$. pumilio. As the quantity of alkaloids in individual frogs increased, so did the number of unique alkaloids acquired. Likewise, alkaloid cocktails in the present study inhibited the growth of A. hydrophila and $K$. pneumoniae more effectively as alkaloid quantity and 
alkaloid diversity increased. Accordingly, alkaloid cocktails from Finca los Nacientes and Tortuguero frogs inhibited growth of A. hydrophila and K. pneumoniae most effectively of all populations in both assays. Finca los Nacientes frogs were protected by alkaloid defenses that were, on average, nearly threefold greater in quantity and $40-100 \%$ more diverse than those La Selva, Río Palmas, and Gandoca frogs. Alkaloid cocktails from Tortuguero frogs were comparable in quantity to alkaloids from Finca los Nacientes frogs, but were instead similar in diversity to alkaloids from La Selva and Río Palmas frogs and higher in diversity than Gandoca. Additionally, the predominant alkaloids present in Finca los Nacientes frog alkaloid cocktails (comprising about half of the total quantity) included 5,8-disubstituted indolizidines, decahydroquinolines, and histrionicotoxins, whereas the most abundant alkaloids in Tortuguero frogs (over $60 \%$ of the total quantity) were 5,8-disubstituted indolizidines and 5,6,8-trisubstituted indolizidines. On the basis of these findings, larger quantities of more diverse alkaloids provided enhanced antimicrobial protection, but 5,8-disubstituted indolizidines, 5,6,8-trisubstituted indolizidines, decahydroquinolines, and histrionicotoxins may also be particularly inhibitory alkaloid classes.

All populations of $O$. pumilio in the present study contained disproportionately high quantities and numbers of mite-derived, branched-chain alkaloids, such as 5,8-disubstituted indolizidines and 5,6,8-trisubstituted indolizidines, which is typical of Costa Rican O. pumilio (Saporito et al. 2007b, 2009, 2011, 2015; Bolton et al. 2017). However, the alkaloid cocktails from the same populations also varied widely in inhibitory efficacy despite sharing large proportions of these common mite-derived alkaloids. The large quantities of these common alkaloids present in the more inhibitory Finca los Nacientes and Tortuguero frogs suggest that these alkaloids may become particularly inhibitory above a certain threshold, which could explain the comparatively reduced inhibition by other populations that share these same alkaloids, but in lower quantities. Alternatively, Finca los Nacientes frogs also contained distinctly high quantities of ant-derived decahydroquinoline and histrionicotoxin alkaloids when compared to other populations, which may also play an important role in Finca los Nacientes frogs' markedly effective inhibition. Although these findings from both mite- and ant-derived alkaloids suggest that alkaloid quantity contributes more to microbial growth inhibition than alkaloid diversity, the acquisition of such extreme quantities of alkaloid defenses presumably takes years to accrue in individual frogs. Interestingly, inhibition by La Selva frogs indicates that tremendous quantities of alkaloids, such as those present in frogs from Finca los Nacientes and Tortuguero, are not necessary for comparable protection.

In the present study, alkaloid diversity varied considerably, from an average of 26 unique alkaloids in Gandoca frogs to 54 unique alkaloids in Finca los Nacientes frogs, although Tortuguero, La Selva, and Río Palmas frogs contained the average 38 unique alkaloids per frog. The alkaloid defenses of frogs from La Selva and Gandoca were virtually identical in terms of average quantity, but Gandoca alkaloids were about $25 \%$ less diverse than those from La Selva, representing a unique opportunity to compare microbial growth inhibition and alkaloid diversity with quantity held constant. In both OD and CFU assays with A. hydrophila, Gandoca frog alkaloids were the least inhibitory of all populations, in accord with their low diversity. In contrast, La Selva frog alkaloid cocktails inhibited A. hydrophila virtually as well as those from Finca los Nacientes and Tortuguero, despite having $300 \%$ lower quantities of less diverse alkaloids. These findings may indicate that microbial inhibition increases at a progressively reduced rate after a certain threshold in the quantity and/or diversity of alkaloids (e.g., average quantity and diversity of La Selva frogs), and also clearly demonstrates that increased alkaloid diversity has the potential to considerably enhance microbial growth inhibition.

In certain cases, however, a high diversity of alkaloids may not be enough to compensate for low quantities of alkaloids. For instance, the alkaloid cocktails of Río Palmas frogs were marginally more diverse than those from Tortuguero frogs, yet inhibited growth of $K$. pneumoniae the least effectively of all populations. Such substantially reduced growth inhibition of K. pneumoniae by Río Palmas frog alkaloids was most likely a result of having the lowest quantities of alkaloids of all populations, despite their high diversity. In this case, the average quantity of alkaloids in Río Palmas frogs may have been comparatively far below the hypothetical threshold quantity after which gains in microbial inhibition diminish. Moreover, if such a threshold quantity exists, then particular alkaloid classes are likely required rather than any arbitrary suite of alkaloids. Coincidentally, the already low quantities of alkaloids in Río Palmas frogs were also evenly distributed among the identified alkaloid structural classes, which was not the case in other populations. For example, the five most abundant alkaloids among Río Palmas frogs were each of a different structural class and comprised just $28 \%$ of the population's total $\sim 3700 \mu \mathrm{g}$ of alkaloids, whereas the five most abundant alkaloids in the more inhibitory Tortuguero frog alkaloid cocktails comprised just the two most common structural classes (5,8-disubstituted and 5,6,8-trisubstituted indolizidines) and $62 \%$ of Tortuguero's total $\sim 14,000 \mu \mathrm{g}$ of alkaloids. Accordingly, optimal growth inhibition likely requires certain quantities of specific types of alkaloids, although even comparatively low quantities (e.g., Río Palmas) and diversities (e.g., Gandoca) of alkaloids can inhibit the growth of these pathogens to an extent.

Alkaloid defenses from all five populations of $O$. pumilio effectively inhibited growth of the opportunistic, Gramnegative bacteria $A$. hydrophila and $K$. pneumoniae, although 
OD and CFU assays suggest slightly different interpretations of the results. For example, growth inhibition approximated by OD assays indicated that certain populations of $O$. pumilio, such as Río Palmas and Gandoca, did not effectively inhibit the growth of these pathogens compared to control, which may indicate that they are susceptible to infection. However, as evident from CFU assays, treatment with alkaloid cocktails from these same locations significantly reduced the amount of viable bacterial cells persisting after $24.5 \mathrm{hr}$ in A. hydrophila and $K$. pneumoniae cultures compared to control, which suggests that alkaloid cocktails from Río Palmas and Gandoca are effective antimicrobial agents. These observations of effective growth inhibition in CFU assays but not OD assays demonstrate the value of CFU assays, and may in fact provide a more ecologically valid assessment of antimicrobial efficacy. The discrepancies in effective growth inhibition between OD and CFU assays for Río Palmas and Gandoca frogs are likely explained by each assay's measured growth variable; OD assays measured the density of both live and dead cells suspended in solution, whereas CFU assays evaluated the quantity of viable (i.e., able to multiply via binary fission) bacterial cells remaining after treatment with $O$. pumilio alkaloid cocktails. Moreover, OD assays and CFU assays were strongly correlated, and the relative patterns of growth inhibition among populations are nearly identical between OD assays and CFU assays, wherein the most (Finca los Nacientes and/or Tortuguero) and least inhibitory (Río Palmas and/or Gandoca) populations were consistent between assays for each pathogen.

On the basis of the relationships among O. pumilio alkaloid quantity, diversity and microbial growth inhibition in the present study, the efficacy of alkaloid-based microbial growth inhibition appears to increase most notably when alkaloid defenses comprise sufficient (e.g., $>400 \mu \mathrm{g}$ per frog skin) quantities of diverse suites of alkaloids (e.g., >30 individual alkaloids), and when there are high quantities of certain types of alkaloids. In other words, although the general quantity and diversity of alkaloids in poison frog defenses undoubtedly drive variation among populations, the presence of specific types of alkaloids also likely plays an important role in microbial growth inhibition. Overall, these findings support the hypothesis that alkaloid defenses from distinct populations of $O$. pumilio inhibit pathogens to different degrees, which may influence how those populations respond to emerging infectious pathogens.

Individual alkaloids inhibit the growth of the bacteria $B$. subtilis and $E$. coli to varying degrees or not at all (Macfoy et al. 2005), which indicates that alkaloid types differ in their inhibitory activity against specific types of microbes (e.g., Gram-negative or Gram-positive bacteria, or various fungi, viruses, etc.). For instance, Macfoy et al. (2005) report that nearly all individual assayed alkaloids inhibited the growth of $B$. subtilis, whereas only a piperidine alkaloid inhibited $E$. coli. Similarly, certain individual pyrrolidine, piperidine, decahydroquinoline, and pumiliotoxin alkaloids effectively inhibited growth of the fungus C. albicans (Macfoy et al. 2005). In contrast, Mina et al. (2015) reported that C. albicans was inhibited only by Isla Solarte (Panama) frog alkaloid cocktails containing primarily decahydroquinolines and pumiliotoxin alkaloids, although alkaloid cocktails from Puerto Viejo (Costa Rica) frogs, consisting of large amounts of decahydroquinolines and histrionicotoxins, also inhibited C. albicans somewhat effectively. These findings are consistent with results from the present study in concluding that certain alkaloid classes such as decahydroquinolines and histrionicotoxins, which are unbranched-chain alkaloids derived from ants (Spande et al. 1999; Daly et al. 2005; Jones et al. 2012), may be particularly inhibitory. However, microbial inhibition by alkaloid defenses appears to be influenced by more than just the presence of specific alkaloid types.

Important complementary and/or synergistic relationships among sequestered alkaloids may enhance protection from pathogens in poison frogs. For example, while the aforementioned individual alkaloids differ in terms of which types of bacteria they can inhibit (Macfoy et al. 2005), natural alkaloid cocktails from $O$. pumilio that contain a diversity of alkaloids consistently inhibit the same bacteria (Mina et al. 2015). In synthesized amphibian chemical defenses, such as antimicrobial peptides, a combination of various peptides is more effective than the individual peptides at inhibiting pathogenic microbes, including A. hydrophila (Rollins-Smith et al. 2002a, b; Rollins-Smith 2005; Rosenfeld et al. 2006; Conlon 2011a). Additionally, more diverse suites of peptides have been proposed to provide protection from a wider range of pathogens by enhancing other peptides' inhibitory activity (i.e., synergy), or by different peptides or classes targeting different classes of microbes (i.e., complementary) (Nicolas and Mor 1995; Simmaco et al. 1998b; Zasloff 2002; Tennessen et al. 2009). Based on previous alkaloid-based microbial inhibition research and relationships between inhibition and alkaloid composition from the present study, similar synergistic and/or complementary effects may occur in sequestered alkaloid defenses, where comparatively diverse alkaloid cocktails provide enhanced protection from a wider range of pathogens.

Much like antimicrobial peptides, alkaloid defenses in poison frogs may provide dual predator and pathogen protection. For example, prospective predators that sample and ultimately reject poison frogs as a prey item (Brodie and Tumbarello 1978; Fritz et al. 1981; Szelistowski 1985; Gray et al. 2010; Stynoski et al. 2014; Hantak et al. 2016; Hovey et al. 2016; Murray et al. 2016) stimulate the secretion of defensive alkaloids onto the skin, and may inflict wounds that could be 
potentially fatal if infected. In this case, poison frog alkaloid secretions could potentially reduce wound infection and inhibit the growth of non-residential microbes including pathogens. While most amphibian antimicrobial peptides exert activity through pore formation in cellular mebranes (Yang et al. 2001; Brogden 2005; Diamond et al. 2009; Chen et al. 2012), more research is needed on the antimicrobial capacity and mechanism of action of poison frog alkaloids. However, it should be noted that a resident microbiota community almost certainly persists in the presence of alkaloid defenses (Culp et al. 2007; Lauer et al. 2007; Walke et al. 2015). Additionally, it is feasible that incipient infections in poison frogs may elicit a stress response that stimulates smooth muscle around granular glands, thereby inducing the secretion of additional alkaloids onto the skin to reduce the viable infection load. For instance, Rana esculenta and Bombina orientalis induce and/or upregulate synthesized antimicrobial peptide defenses after exposure to microbes, including A. hydrophila (Miele et al. 1998; Simmaco et al. 1998a; Mangoni et al. 2001). Sequestration of arthropod-derived alkaloids by poison frogs may therefore be analogous in some ways to synthesized peptide defenses (Zasloff 1987; Pask et al. 2013) and play an important role in protection from infectious pathogens, especially when the innate immune system is compromised or the frog is wounded.

Amphibians are inhabited by communities of microbes (e.g., gut-associated microbes and skin-associated microbes), some of which are symbiotic and complement their innate immune system by defending the host from infectious pathogens (Culp et al. 2007; Lauer et al. 2007, 2008; Woodhams et al. 2007a, b, c; Myers et al. 2012; Park et al. 2014; Becker et al. 2015). Conversely, certain Gram-negative gut- or skinresident microbes that are frequently isolated from wild and captive frogs, such as A. hydrophila and K. pneumoniae (Bradford 1991; Barra et al. 1998), can cause fatal systemic infections in immunocompromised amphibians (Carr et al. 1976; Hubbard 1981). Of these microbes, A. hydrophila in particular has been linked to wild and captive population amphibian declines (Nyman 1986; Pearson et al. 2000; Miller et al. 2008; Hill et al. 2010). The resistance and resulting virulence of $A$. hydrophila appears to be due to its production of extracellular proteases that break down amphibian antimicrobial peptides, rendering these synthesized chemical defenses largely ineffective (Rollins-Smith et al. 2002a; Schadich and Cole 2009). Metabolites of Phyllomedusa distincta skin microbiota also effectively inhibited growth of E. coli and other microbes in an optical density-based growth inhibition assay, whereas A. hydrophila was most resistant to growth inhibition. Additionally, K. pneumoniae was not inhibited by the same metabolites, although in a separate streak assay (Brito de Assis et al. 2016). In the present study, alkaloid cocktails from all populations of $O$. pumilio clearly inhibited the resistant pathogen $A$. hydrophila and the relatively resistant, more pathogenic, $K$. pneumoniae. The conclusion that poison frog alkaloids can reliably inhibit $A$. hydrophila may indicate that the extracellular proteases produced by the pathogen are inactive against sequestered alkaloids, especially given that those proteolytic compounds confer $A$. hydrophila resistance to antimicrobial peptides (Rollins-Smith et al. 2002a; Tennessen et al. 2009; Brito de Assis et al. 2016). This is consistent with the hypothesis that $A$. hydrophila proteases coevolved specifically with widespread amphibian chemical defenses, such as synthesized peptides or microsymbiont-derived metabolites, as an adaptation to survive on amphibian skin (Schadich and Cole 2009). Alternatively, the mechanism of action of poison frog alkaloids may simply be more effective against $A$. hydrophila and $K$. pneumoniae than that of the antimicrobial peptides and metabolites studied so far. However, the same antimicrobial peptides that do not inhibit $A$. hydrophila can effectively inhibit the pathogen most closely associated with global amphibian population declines and biodiversity loss, Batrachochytrium dendrobatidis (Berger et al. 1998; Rollins-Smith et al. 2002b). The inhibitory activity of sequestered alkaloid defenses against $B d$ is not yet known. Thus, although findings from the present study demonstrate that poison frog alkaloids can function as an effective defense against virulent pathogens, the inhibitory activity of alkaloid defenses against other highly-relevant pathogens remains to be determined.

Our results demonstrate that alkaloid-based chemical defenses in the dendrobatid poison frog $O$. pumilio inhibit the growth of known anuran pathogens, and may function as a defense against both predators and pathogenic microorganisms. Much like variation in alkaloid defenses is hypothesized to play a role in defense against predators (Saporito et al. 2006, 2007a; Murray et al. 2016), these findings suggest that the natural variation in poison frog alkaloid defenses influences protection from pathogenic microbes. Although the antimicrobial activity of alkaloid cocktails from other poison frog lineages have not been studied, similar variation may be observed given the comparable variation in dietary arthropods (Clark et al. 2006; Bonansea and Vaira 2007; Daly et al. 2008a; Quiroga et al. 2011; Andriamaharavo et al. 2015). However, the pathogens used in the present study do not pose a particularly significant threat to amphibian biodiversity. Future studies should aim to assess the effectiveness of sequestered alkaloid defenses from multiple poison frog lineages against pathogens associated with emerging infectious diseases and widespread amphibian population declines, such as ranaviruses and $B d$ (Pessier 2002; Whitfield et al. 2013). 
Acknowledgements This study was supported by an Exploration Fund Grant from The Explorers Club, a Roger Conant Grant In Herpetology from the Society for the Study of Amphibians and Reptiles, a Grant-InAid of Research from Sigma Xi, The Scientific Research Society, and John Carroll University. We thank the Organization for Tropical Studies La Selva Biological Research Station, the Canadian Organization for Tropical Education and Rainforest Conservation Caño Palma Biological Station, Emily Khazan, Alex C. Gilman, and Andres Vega for their support in carrying out this research, as well as N. Becza, A. Blanchette, S. Bolton, M. Boyk, R. Drenovsky, M. Gade, M. Russell, N. Spies, M. Viloria, and N. Woodcraft for helpful editorial feedback and/or assistance collecting frogs. All collections of $O$. pumilio were approved by the Convention on International Trade of Endangered Species (CITES) research and collection permit 2015-CR1420/SJ(\#S1487) issued by the Costa Rican government. The John Carroll University Institutional Animal Care and Use Committee (IACUC protocol \#1101) approved all methods used in the study.

\section{References}

Andriamaharavo NR, Garraffo HM, Spande TF, Giddings L-A, Vieites DR, Vences M, Saporito RA (2015) Individual and geographic variation of skin alkaloids in three swamp-forest species of Madagascan poison frogs (Mantella). J Chem Ecol 41:837-847

Barra D, Simmaco M, Boman HG (1998) Gene-encoded peptide antibiotics and innate immunity. Do "animalcules" have defence budgets? FEBS Lett 430:130-134

Becker MH, Harris RN (2010) Cutaneous bacteria of the redback salamander prevent morbidity associated with a lethal disease. PLoS One 5:e10957

Becker MH, Walke JB, Cikanek S, Savage AE, Mattheus N, Santiago CN, Minbiole KPC, Harris RN, Belden LK, Gratwicke B (2015) Composition of symbiotic bacteria predicts survival in Panamanian golden frogs infected with a lethal fungus. Proc R Soc B 282: 20142881

Berger L, Speare R, Daszak P, Green DE, Cunningham AA, Goggin CL, Slocombe R, Ragan MA, Hyatt AD, McDonald KR, Hines HB, Lips KR, Marantelli G, Parkes H (1998) Chytridiomycosis causes amphibian mortality associated with population declines in the rain forests of Australia and central America. Proc Natl Acad Sci U S A 95:9031-9036

Bolton SK, Dickerson K, Saporito RA (2017) Variable alkaloid defense in the dendrobatid poison frog (Oophaga pumilio) are perceived as differences in palatability to arthropods. J Chem Ecol 43:273-289

Bonansea MI, Vaira M (2007) Geographic variation of the diet of Melanophryniscus rubriventris (Anura: Bufonidae) in northwestern Argentina. J Herpetol 41:231-236

Bradford DF (1991) Mass mortality and extinction in a high-elevation population of Rana muscosa. J Herpetol 25:174-177

Brito de Assis A, dos Santos C, Dutra FP, de Oliveira Motta A, Costa FS, Navas CA, Magalhães BS, Barreto CC (2016) Assessing antibacterial potential of components of Phyllomedusa distincta skin and its associated dermal microbiota. J Chem Ecol 42:139-148

Brodie ED, Tumbarello MS (1978) The antipredator functions of Dendrobates auratus (Amphibia, Anura, Dendrobatidae) skin secretion in regard to a snake predator (Thamnophis). J Herpetol 12:264-265

Brogden KA (2005) Antimicrobial peptides: pore formers or metabolic inhibitors in bacteria? Nat Rev Microbiol 3:238-250

Brucker RM, Harris RN, Schwantes CR, Gallaher TN, Flaherty DC, Lam BA, Minbiole KPC (2008) Amphibian chemical defense: antifungal metabolites of the microsymbiont Janthinobacterium lividum on the salamander Plethodon cinereus. J Chem Ecol 34:1422-1429
Cardall BL, Brodie ED, Hanifin CT (2004) Secretion and regeneration of tetrodotoxin in the rough-skin newt (Taricha granulosa). Toxicon 44:933-938

Carr AH, Amborski RL, Culley DDJ, Amborski GF (1976) Aerobic bacteria in the intestinal tracts of bull-frogs (Rana catesbeiana) maintained at low temperatures. Herpetologica 32:239-244

Chen L, Gao L, Fang W, Golubovic L (2012) How the antimicrobial peptides kill bacteria: computational physics insights. Commun Comput Phys 11:709-725

Clark VC, Rakotomalala V, Ramilijaona O, Abrell L, Fisher BL (2006) Individual variation in alkaloid content of poison frogs of Madagascar (Mantella; Mantellidae). J Chem Ecol 32:2219-2233

Conlon JM (2011a) Structural diversity and species distribution of host-defense peptides in frog skin secretions. Cell Mol Life Sci 68:2303-2315

Conlon JM (2011b) The contribution of skin antimicrobial peptides to the system of innate immunity in anurans. Cell Tissue Res 343:201-212

Culp CE, Falkinham JOI, Belden LK (2007) Identification of the natural bacterial microflora on the skin of eastern newts, bullfrog tadpoles and redback salamanders. Herpetologica 63:66-71

Daly JW (1995) The chemistry of poisons in amphibian skin. Proc Natl Acad Sci U S A 92:9-13

Daly JW (2004) Marine toxins and nonmarine toxins: convergence or symbiotic organisms? J Nat Prod 67:1211-1215

Daly JW, Garraffo HM (1990) Alkaloids from Australian frogs (Myobatrachidae): Pseudophrynamines and pumiliotoxins. J Nat Prod 5:407-421

Daly JW, Myers CW, Whittaker N (1987) Further classification of skin alkaloids from neotropical poison frogs (Dendrobatidae), with a general survey of toxic/noxious substances in the Amphibia. Toxicon 25:1023-1095

Daly JW, Garraffo HM, Spande TF, Jaramillo C, Rand AS (1994) Dietary source for skin alkaloids of poison frogs (Dendrobatidae)? J Chem Ecol 20:943-955

Daly JW, Garraffo HM, Hall GSE, Cover JF (1997) Absence of skin alkaloids in captive-raised Madagascan mantelline frogs (Mantella) and sequestration of dietary alkaloids. Toxicon 35: 1131-1135

Daly JW, Kaneko T, Wilham JM, Garraffo HM, Spande TF, Espinosa A, Donnelly MA (2002) Bioactive alkaloids of frog skin: combinatorial bioprospecting reveals that pumiliotoxins have an arthropod source. Proc Natl Acad Sci U S A 99:13996-14001

Daly JW, Spande TF, Garraffo HM (2005) Alkaloids from amphibian skin: a tabulation of over eight-hundred compounds. J Nat Prod 68:1556-1575

Daly JW, Wilham JM, Spande TF, Garraffo HM, Gil RR, Silva GL, Vaira M (2007) Alkaloids in bufonid toads (Melanophryniscus): temporal and geographic determinants for two Argentinian species. J Chem Ecol 33:871-887. https://doi.org/10.1007/s10886-007-9261-x

Daly JW, Garraffo HM, Spande TF, Giddings L-A, Saporito RA, Vieites DR, Vences M (2008a) Individual and geographic variation of skin alkaloids in three species of Madagascan poison frogs (Mantella). $\mathrm{J}$ Chem Ecol 34:252-279

Daly JW, Garraffo HM, Spande TF, Yeh HJC, Peltzer PM, Cacivio P, Baldo JD, Faivovich J (2008b) Indolizidine 239Q and Quinolizidine 275I. Major alkaloids in two Argentinian bufonid toads (Melanophryniscus). Toxicon 52:858-870

Daly JW, Ware N, Saporito RA, Spande TF, Garraffo HM (2009) Nmethyldecahydroquinolines: an unexpected class of alkaloids from Amazonian poison frogs (Dendrobatidae). J Nat Prod 72:1110-1114

Diamond G, Beckloff N, Weinberg A, Kisich KO (2009) The roles of antimicrobial peptides in innate host defense. Curr Pharm Des 15: 2377-2392

Donnelly MA (1989) Reproductive phenology and age structure of Oophaga pumilio in northeastern Costa Rica. J Herpetol 23: 362-367 
Edmunds M (1974) Defence in animals. Longman, Harlow

Erspamer V (1994) Bioactive secretions of the amphibian integument. In: Heatwole H, Barthalmus G, Heatwole A (eds) Amphibian biology. Surrey Beatty and Sons, Chipping Norton

Fitch RW, Spande TF, Garraffo HM, Yeh HJC, Daly JW (2013) Phantasmidine: an epibatidine congener from the Ecuadorian poison frog Epipedobates anthonyi. J Nat Prod 73:331-337

Fritz G, Rand AS, Claude W (1981) The aposematically colored frog, Dendrobates pumilio, is distasteful to the large, predatory ant, Paraponera clavata. Biotropica 13:158-159

Garraffo HM, Andriamaharavo NR, Vaira M, Quiroga MF, Heit C, Spande TF (2012) Alkaloids from single skins of the Argentinian toad Melanophryniscus rubriventris (Anura, Bufonidae): an unexpected variability in alkaloid profiles and a profusion of new structures. Spring 1:51

Grant T, Colombo P, Verrastro L, Saporito RA (2012) The occurrence of defensive alkaloids in non-integumentary tissues of the Brazilian red-belly toad Melanophryniscus simplex (Bufonidae). Chemoecology 22:169-178

Gray HM, Kaiser H, Green DM (2010) Does alkaloid sequestration protect the green poison frog, Dendrobates auratus, from predator attacks? Salamandra 46:235-238

Green SL, Bouley DM, Tolwani RJ, Waggie KS, Lifland BD, Otto GM, Ferrell JE (1999) Identification and management of an outbreak of Flavobacterium meningosepticum infection in a colony of south African clawed frogs (Xenopus laevis). J Am Vet Med Assoc 214: $1833-1838$

Green DE, Converse KA, Schrader AK (2002) Epizootiology of sixty four amphibian morbidity and mortality events in the USA, 19962001. Ann N Y Acad Sci 969:323-339

Hantak MM, Grant T, Reinsch S, Mcginnity D, Loring M, Toyooka N, Saporito RA (2013) Dietary alkaloid sequestration in a poison frog: an experimental test of alkaloid uptake in Melanophryniscus stelzneri (Bufonidae). J Chem Ecol 39:1400-1406

Hantak MM, Paluh DJ, Saporito RA (2016) Bufadienolide and alkaloidbased chemical defences in two different species of neotropical anurans are equally effective against the same arthropod predators. $\mathrm{J}$ Trop Ecol 32:165-169

Harris RN, Brucker RM, Walke JB, Becker MH, Schwantes CR, Flaherty DC, Lam BA, Woodhams DC, Briggs CJ, Vredenburg VT, Minbiole KPC (2009) Skin microbes on frogs prevent morbidity and mortality caused by a lethal skin fungus. ISME J 3:818-824

Hill WA, Newman SJ, Craig L, Carter C, Czarra J, Brown JP (2010) Diagnosis of Aeromonas hydrophila, Mycobacterium species, and Batrachochytrium dendrobatidis in an African clawed frog (Xenopus laevis). J Am Assoc Lab Anim Sci 49:215-220

Hovey KJ, Viloria MO, Saporito RA (2016) Oophaga pumilio (strawberry poison frog). Predator-prey interactions. Herpetol Rev 47: $113-114$

Hubbard GB (1981) Aeromonas hydrophila infection in Xenopus laevis. Lab Anim Sci 31:297-300

Jeckel AM, Grant T, Saporito RA (2015a) Sequestered and synthesized chemical defenses in the poison frog Melanophryniscus moreirae. $\mathrm{J}$ Chem Ecol 41:505-512

Jeckel AM, Saporito RA, Grant T (2015b) The relationship between poison frog chemical defenses and age, body size, and sex. Front Zool 12:27

Jones TH, Adams RMM, Spande TF, Garraffo HM, Kaneko T, Schultz TR (2012) Histrionicotoxin alkaloids finally detected in an ant. J Nat Prod 75:1930-1936

Lauer A., Simon MA, Banning JL, Lam BA, Harris RN (2008) Diversity of cutaneous bacteria with antifungal activity isolated from female four-toed salamanders. The ISME J 2:145-157

Lauer A, Simon MA, Banning JL, André E, Duncan K, Harris RN (2007) Common cutaneous bacteria from the eastern red-backed salamander can inhibit pathogenic fungi. Copeia 2007:630-640
Loudon AH, Woodhams DC, Parfrey LW, Archer H, Knight R, McKenzie VJ, Harris RN (2014) Microbial community dynamics and effect of environmental microbial reservoirs on red-backed salamanders (Plethodon cinereus). ISME J 8:830-840

Macfoy C, Danosus D, Sandit R, Jones TH, Garraffo HM, Spande TF, Daly JW (2005) Alkaloids of anuran skin: antimicrobial function? Zeitschrift für Naturforsch C 60:932-937

Mangoni ML, Miele R, Renda TG, Barra D, Simmaco M (2001) The synthesis of antimicrobial peptides in the skin of Rana esculenta is stimulated by microorganisms. FASEB J 15:1431-1432

McClean S, Robinson RC, Shaw C, Smyth WF (2002) Characterisation and determination of indole alkaloids in frog-skin secretions by electrospray ionisation ion trap mass spectrometry. Rapid Commun Mass Spectrom 16:346-354

Mebs D (2001) Toxicity in animals. Trends in evolution? Toxicon 39:87-96

Miele R, Ponti D, Boman HG, Barra D, Simmaco M (1998) Molecular cloning of a bombinin gene from Bombina orientalis: detection of NF-KB and NF-IL6 binding sites in its promoter. FEBS Lett 431:23-28

Miller D, Rajeev S, Brookins M, Cook J, Whittington L, Baldwin C (2008) Concurrent infection with ranavirus, Batrachochytrium dendrobatidis, and Aeromonas in a captive anuran colony. J Zoo Wildl Med 39:445-449

Mina AE, Ponti AK, Woodcraft NL, Johnson EE, Saporito RA (2015) Variation in alkaloid-based microbial defenses of the dendrobatid poison frog Oophaga pumilio. Chemoecology 25:169-178

Murray EM, Bolton SK, Berg T, Saporito RA (2016) Arthropod predation in a dendrobatid poison frog: does frog life stage matter? Zoology 119:119-126

Myers CW, Daly JW (1976) Preliminary evaluation of toxins and vocalizations in taxonomic and evolutionary studies of poison-dart frogs (Dendrobatidae). Bull Am Mus Nat Hist 157:173-262

Myers JM, Ramsey JP, Blackman AL, Nichols AE, Minbiole KPC, Harris RN (2012) Synergistic inhibition of the lethal fungal pathogen Batrachochytrium dendrobatidis: the combined effect of symbiotic bacterial metabolites and antimicrobial peptides of the frog Rana muscosa. J Chem Ecol 38:958-965

Nicolas P, Mor A (1995) Peptides as weapons against microorganisms in the chemical defense system of vertebrates. Annu Rev Microbiol: 277-304

Nyman S (1986) Mass mortality in larval Rana sylvatica attributable to the bacterium, Aeromonas hydrophila. J Herpetol 20:196-201

Park ST, Collingwood AM, St-Hilaire S, Sheridan PP (2014) Inhibition of Batrachochytrium dendrobatidis caused by bacteria isolated from the skin of boreal toads, Anaxyrus (Bufo) boreas boreas, from grand Teton National Park, Wyoming, USA. Microbiol Insights 7:1-8

Pask JD, Cary TL, Rollins-Smith LA (2013) Skin peptides protect juvenile leopard frogs (Rana pipiens) against chytridiomycosis. J Exp Biol 216:2908-2916

Pearson MD, Hirono I, Aoki T, Miranda R, Inglis V (2000) Virulence properties of motile aeromonads isolated from farmed frogs Rana tigerina and R. rugulosa. Dis Aquat Org 40:185-193

Pessier AP (2002) An overview of amphibian skin disease. Semin Avian Exot Pet Med 11:162-174

Quiroga MF, Bonansea MI, Vaira M (2011) Population diet variation and individual specialization in the poison toad, Melanophryniscus rubriventris (Vellard, 1947). Amphibia-Reptilia 32:261-265

Roelants K, Fry BG, Ye L, Stijlemans B, Brys L, Kok P, Clynen E, Schoofs L, Cornelis P, Bossuyt F (2013) Origin and functional diversification of an amphibian defense peptide arsenal. PLoS Genet 9:e1003662

Rollins-Smith LA (2005) Antimicrobial peptide defenses in amphibian skin. Integr Comp Biol 45:137-142

Rollins-Smith LA, Carey C, Longcore JE, Doersam JK, Boutte A, Bruzgal JE, Conlon JM (2002a) Activity of antimicrobial skin 
peptides from ranid frogs against Batrachochytrium dendrobatidis, the chytrid fungus associated with global amphibian declines. Dev Comp Immunol 26:471-479

Rollins-Smith LA, Doersam JK, Longcore JE, Taylor SK, Shamblin JC, Carey C, Zasloff MA (2002b) Antimicrobial peptide defenses against pathogens associated with global amphibian declines. Dev Comp Immunol 26:63-72

Rosenfeld Y, Barra D, Simmaco M, Shai Y, Mangoni ML (2006) A synergism between temporins toward gram-negative bacteria overcomes resistance imposed by the lipopolysaccharide protective layer. J Biol Chem 281:28565-28574

Santos JC, Tarvin RD, O'Connell LA (2016) A review of chemical defense in poison frogs (Dendrobatidae): ecology, pharmacokinetics, and autoresistance. In: Schulte BE, Goodwin TE, Ferkin MH (eds) Chemical signals in vertebrates 13. Springer International Publishing, New York City, pp 305-337

Saporito RA, Donnelly MA, Garraffo HM, Spande TF, Daly JW (2006) Geographic and seasonal variation in alkaloid-based chemical defenses of Dendrobates pumilio from Bocas del Toro, Panama. J Chem Ecol 32:795-814

Saporito RA, Donnelly MA, Jain P, Garraffo HM, Spande TF, Daly JW (2007a) Spatial and temporal patterns of alkaloid variation in the poison frog Oophaga pumilio in Costa Rica and Panama over 30 years. Toxicon 50:757-778

Saporito RA, Donnelly MA, Norton RA, Garraffo HM, Spande TF, Daly JW (2007b) Oribatid mites as a major dietary source for alkaloids in poison frogs. Proc Natl Acad Sci U S A 104:8885-8890

Saporito RA, Spande TF, Garraffo HM, Donnelly MA (2009) Arthropod alkaloids in poison frogs: a review of the "dietary hypothesis". Heterocycles 79:277-297

Saporito RA, Donnelly MA, Madden AA, Garraffo HM, Spande TF (2010a) Sex-related differences in alkaloid chemical defenses of the dendrobatid frog Oophaga pumilio from Cayo Nancy, Bocas del Toro, Panama. J Nat Prod 73:317-321

Saporito RA, Isola M, Maccachero VC, Condon K, Donnelly MA (2010b) Ontogenetic scaling of poison glands in a dendrobatid poison frog. J Zool 282:238-245

Saporito RA, Norton RA, Andriamaharavo NR, Garraffo HM, Spande TF (2011) Alkaloids in the mite Scheloribates laevigatus: further alkaloids common to oribatid mites and poison frogs. J Chem Ecol 37: 213-218

Saporito RA, Donnelly MA, Spande TF, Garraffo HM (2012) A review of chemical ecology in poison frogs. Chemoecology 22:159-168

Saporito RA, Norton RA, Garraffo HM, Spande TF (2015) Taxonomic distribution of defensive alkaloids in Nearctic oribatid mites (Acari, Oribatida). Exp Appl Acarol 67:317-333

Schadich E, Cole ALJ (2009) Inhibition of frog antimicrobial peptides by extracellular products of the bacterial pathogen Aeromonas hydrophila. Lett Appl Microbiol 49:384-387

Schadich E, Cole ALJ (2010) Pathogenicity of Aeromonas hydrophila, Klebsiella pneumoniae, and Proteus mirabilis to brown tree frogs (Litoria ewingii). Comp Med 60:114-117

Sherman CK, Morton ML (1993) Population declines of Yosemite toads in the eastern sierra Nevada of California. J Herpetol 27:186-198

Simmaco M, Mangoni ML, Boman A, Barra D, Boman HG (1998a) Experimental infections of Rana esculenta with Aeromonas hydrophila: a molecular mechanism for the control of the normal flora. Scand J Immunol 48:357-363

Simmaco M, Mignogna G, Barra D (1998b) Antimicrobial peptides from amphibian skin: what do they tell us? Biopolym - Pept Sci Sect 47: 435-450

Smith BP, Tyler MJ, Kaneko T, Garraffo HM, Spande TF, Daly JW (2002) Evidence for biosynthesis of pseudophrynamine alkaloids by an Australian microhylid frog (Pseudophryne) and for sequestration of dietary pumiliotoxins. J Nat Prod 65:439-447
Spande TF, Jain P, Garraffo HM, Pannell LK, Yeh HJC, Daly JW, Fukumoto S, Imamura K, Tokuyama T, Torres JA, Snelling RR, Jones TH (1999) Occurrence and significance of decahydroquinolines from dendrobatid poison frogs and a myrmicine ant: use of $1 \mathrm{H}$ and 13C NMR in their conformational analysis. J Nat Prod 62:5-21

Stynoski JL, Torres-Mendoza Y, Sasa-Marin M, Saporito RA (2014) Evidence of maternal provisioning of alkaloid-based chemical defenses in the strawberry poison frog Oophaga pumilio. Ecology 95: $587-593$

Szelistowski WA (1985) Unpalatability of the poison arrow frog Dendrobates pumilio to the ctenid spider Cupiennius coccineus. Biotropica 17:345-346

Taylor SK, Green DE, Wright KM, Whitaker BR (2001) Bacterial diseases. In: Wright KM, Whitaker BR (eds) Amphibian medicine and captive husbandry. Krieger Publishing, Malabar, pp 159-179

Tennessen JA, Woodhams DC, Chaurand P, Reinert LK, Billheimer D, Shyr Y, Caprioli RM, Blouin MS, Rollins-Smith LA (2009) Variations in the expressed antimicrobial peptide repertoire of northern leopard frog (Rana pipiens) populations suggest intraspecies differences in resistance to pathogens. Dev Comp Immunol 33: $1247-1257$

Toledo RC, Jared C (1995) Cutaneous granular glands and amphibian venoms. Comp Biochem Physiol Part A Mol Integr Physiol 111A: $1-29$

Walke JB, Becker MH, Loftus SC, House LL, Teotonio TL, Minbiole KPC, Belden LK (2015) Community structure and function of amphibian skin microbes: an experiment with bullfrogs exposed to a chytrid fungus. PLoS One 10:e139848

Weldon PJ, Kramer M, Gordon S, Spande TF, Daly JW (2006) A common pumiliotoxin from poison frogs exhibits enantioselective toxicity against mosquitoes. Proc Natl Acad Sci U S A 103:17818-17821

Weldon PJ, Cardoza YJ, Vander Meer RK, Hoffmann WC, Daly JW, Spande TF (2013) Contact toxicities of anuran skin alkaloids against the fire ant (Solenopsis invicta). Naturwissenschaften 100:185-192

Whitfield SM, Geerdes E, Chacon I, Ballestero Rodriguez E, Jimenez RR, Donnelly MA, Kerby JL (2013) Infection and co-infection by the amphibian chytrid fungus and ranavirus in wild costa Rican frogs. Dis Aquat Org 104:173-178

Woodhams DC, Ardipradja K, Alford RA, Marantelli G, Reinert LK, Rollins-Smith LA (2007a) Resistance to chytridiomycosis varies among amphibian species and is correlated with skin peptide defenses. Anim Conserv 10:409-417

Woodhams DC, Rollins-Smith LA, Alford RA, Simon MA, Harris RN (2007b) Innate immune defenses of amphibian skin: antimicrobial peptides and more. Anim Conserv 10:425-428

Woodhams DC, Vredenburg VT, Simon MA, Billheimer D, Shakhtour B, Shyr Y, Briggs CJ, Rollins-Smith LA, Harris RN (2007c) Symbiotic bacteria contribute to innate immune defenses of the threatened mountain yellow-legged frog, Rana muscosa. Biol Conserv 138: 390-398

Yang L, Harroun TA, Weiss TM, Ding L, Huang HW (2001) Barrel-stave model or toroidal model? A case study on melittin pores. Biophys J $81: 1475-1485$

Yotsu-Yamashita M, Kim YH, Dudley SC, Choudhary G, Pfahnl A, Oshima Y, Daly JW (2004) The structure of zetekitoxin AB, a saxitoxin analog from the Panamanian golden frog Atelopus zeteki: a potent sodium-channel blocker. Proc Natl Acad Sci U S A 101: 4346-4351

Zasloff M (1987) Magainins, a class of antimicrobial peptides from Xenopus skin: isolation, characterization of two active forms, and partial cDNA sequence of a precursor. Proc Natl Acad Sci U S A 84: $5449-5453$

Zasloff M (2002) Antimicrobial peptides of multicellular organisms. Nature 415:389-395 